Western Washington University

Western CEDAR

Summer 1989

\title{
Redefining Archival Identity: Meeting User Needs in the Information Society
}

Randall C. Jimerson Western Washington University

Western Washington University, randall.jimerson@wwu.edu

Follow this and additional works at: https:// cedar.wwu.edu/history_facpubs

Part of the Archival Science Commons

\section{Recommended Citation}

Jimerson, Randall C. Western Washington University, "Redefining Archival Identity: Meeting User Needs in the Information Society" (1989). History Faculty and Staff Publications. 67.

https://cedar.wwu.edu/history_facpubs/67

This Article is brought to you for free and open access by the History at Western CEDAR. It has been accepted for inclusion in History Faculty and Staff Publications by an authorized administrator of Western CEDAR. For more information, please contact westerncedar@wwu.edu. 
Redefining Archival Identity: Meeting User Needs in the Information Society Author(s): Randall C. Jimerson

Source: The American Archivist, Vol. 52, No. 3 (Summer, 1989), pp. 332-340

Published by: Society of American Archivists

Stable URL: http://www.jstor.org/stable/40293362

Accessed: 05-10-2015 16:38 UTC

\section{REFERENCES}

Linked references are available on JSTOR for this article:

http://www.jstor.org/stable/40293362?seq=1\&cid=pdf-reference\#references_tab_contents

You may need to $\log$ in to JSTOR to access the linked references.

Your use of the JSTOR archive indicates your acceptance of the Terms \& Conditions of Use, available at http://www.jstor.org/page/ info/about/policies/terms.jsp

JSTOR is a not-for-profit service that helps scholars, researchers, and students discover, use, and build upon a wide range of content in a trusted digital archive. We use information technology and tools to increase productivity and facilitate new forms of scholarship. For more information about JSTOR, please contact support@jstor.org. 


\title{
Perspective
}

\section{Redefining Archival Identity: Meeting User Needs in the Information Society}

\author{
RANDALL C. JIMERSON
}

\begin{abstract}
In order to avoid becoming irrelevant in the modern information society, archivists must redefine their professional identity and role in society, learn new planning and marketing skills, and establish the importance of archives in meeting user needs. Responding to initiatives launched by the SAA Task Force on Archives and Society, the author argues that archivists should adopt a more user-friendly approach to marketing their services. Marketing differs from public relations and selling products by focusing on customers and their needs. Altering the profession's image requires that individual archivists redefine their own self-image, attitudes, and procedures.
\end{abstract}

\footnotetext{
About the author: Randall C. Jimerson is university archivist and director of Historical Manuscripts and Archives at the University of Connecticut. He is a former president of the New England Archivists and is currently director of its Education Project and a member of the SAA Acquisitions and Appraisal Section steering committee, the Connecticut Historical Records Advisory Board, and the Connecticut State Library Board. He is author of The Private Civil War: Popular Thought During the Sectional Conflict (Baton Rouge: Louisiana State University Press, 1988). This article is derived from a paper presented at the fiftieth annual meeting of the Society of American Archivists in Chicago in August 1986.
} 
The Ghost of ARchives Yet to Come visited me late one Friday afternoon. While refoldering Cooperative Extension Service records, I looked up and saw the black shrouded apparition. It beckoned me to follow, and we soon stood in a gleaming airconditioned room filled with banks of computers and display screens. A brightly colored sign on the door proclaimed DATA ARCHIVE. A digital calendar read 12 September 2001.

Efficient information processors busily answered inquiries about university policies and procedures, student academic and social records, alumni profiles, and faculty publications. Every terminal in the search room was occupied by students or faculty members, but most requests were handled through electronic mail and fax copiers. "Our goal is to provide immediate responses to all types of information needs relating to the university," the computer center manager explained. "Our success rate in satisfying client requests is 99 percent."

The Spirit led me from the room. In an instant, we were descending a dark stairway to the library basement. Following a narrow corridor, we came to a steel door with faded letters spelling UNIVERSITY ARCHIVES. Cautiously, I opened the door. The room was crowded with stacks of ancient Hollinger boxes. Piles of unprocessed papers covered several large tables.

"Ah. You must be a researcher," I heard a voice say. "I was hoping someone would come this week. What do you want? We have old yearbooks, catalogs, and non-current records of ..."'

"'Spirit, enough," I pleaded. "Let us turn back now." Mercifully, the Spirit led me quickly from the room.

"Before you leave, Spirit, tell me this," I beseeched him. "Are these the shadows of the things that will be, or are they only shadows of the things that may be?" The Ghost of Archives Yet to Come did not answer, but only pointed back to the future.
This vision still haunts me. Is this our future as archivists? Will we become quaint anachronisms in a world of instant data communication, high technology, and rapid change? Such questions are troubling. They strike at our professional pride, at our selfesteem. Pity the poor archivist of the future-shunted off to a basement corner, his disappearance unlamented, unnoticed. The motto for the high-tech future may well be: "What is Past is"- not "Prologue," but"Irrelevant."

The twenty-first century is only a decade away. The challenge for archivists-as for our entire society - is to prepare for the increasingly rapid changes we will encounter in coming years. Already we have seen a major shift from an industrial society to an "information society," as John Naisbitt argued in his 1982 best-seller, Megatrends. Information is now the United States' major strategic resource. While industrial production declines, information-related jobs have become the major growth segment of the workplace. Computer literacy will soon be as essential as the "three R's" were a generation ago. Thanks to satellite links, worldwide communication is instantaneous. As Naisbitt writes, the real importance of Sputnik was not that it launched the age of space exploration, but that it introduced the era of global satellite communication. We suffer from information overload. "We are drowning in information, but starved for knowledge," Naisbitt concludes. "Uncontrolled and unorganized information is no longer a resource in an information society ... The emphasis of the whole information society shifts, then, from supply to selection."' Archival appraisal skills should be highly valuable in meeting this challenge.

1John Naisbitt, Megatrends: Ten New Directions Transforming Our Lives (New York: Warner Books, 1982), 12, 24. 


\section{Professional Identity and Professional Planning}

In the midst of these rapid changes in society, the archival profession is going through an identity crisis. The recent flurry of self-analysis efforts marks a healthy questioning of our professional identity. First, the state historical records assessment projects documented, graphically and in great detail, what we already knew about the "cycle of poverty" that hampers our efforts. Funded by the National Historical Publications and Records Commission, these assessment reports provided the first in-depth examination of national historical records programs since the New Deal. Both separately and cumulatively, they reveal the serious financial, personnel, and resource limitations under which archivists work to preserve our documentary heritage. ${ }^{2}$

Second, the Society of American Archivists' Task Force on Goals and Priorities has provided a valuable planning tool to help us chart future directions and priorities. Its report, Planning for the Archival Profession, attempts to provide a framework for planning and decision making and "to promote consensus on major goals and objectives." Although many of the report's recommendations have been embraced by various SAA committees and section steering groups, archivists have been slow to institutionalize planning as an ongoing process. ${ }^{3}$ This is particularly true for individual repositories. Few archival institutions have started systematic planning programs.

\footnotetext{
${ }^{2}$ Lisa B. Weber, ed., Documenting America: Assessing the Condition of Historical Records in the States (Atlanta: National Association of State Archives and Records Administrators, 1984).

'Planning for the Archival Profession: A Report of the SAA Task Force on Goals and Priorities (Chicago: Society of American Archivists, 1986), 1. The continuation of the SAA planning process is shown in $A n$ Action Agenda for the Archival Profession: Institutionalizing the Planning Process (Chicago: Society of American Archivists, 1988).
}

Even certification is primarily an effort in self-definition. It will provide employers, resource allocators, and others with one means of identifying experienced and knowledgeable archivists. Yet its more significant implication, it seems to me, lies in defining the boundaries of professional status. This has both positive and potentially negative connotations. It may enhance the status and self-image of archivists who become certified. But it could also drive a wedge between certified and non-certified archivists, just at the time that we need to broaden our professional networks and strengthen our ties with related professions.

The Task Force on Archives and Society is the only one of these self-analysis efforts that has looked outside the profession for answers. In particular, the Sidney Levy and Albert Robles report, The Image of Archivists: Resource Allocators' Perceptions, holds a mirror for us to see our public image. It isn't as pretty as we would like. Even our positive qualities actually become liabilities, as one summary indicates: " $[\mathrm{W}] \mathrm{e}$ are well liked for our passivity; we are respected for our service, but service is by implication reward enough; we are admired for our curatorial ability, meaning we are quiet, pleasant, and powerless." 4

To improve our status, however, we must understand how others see us. Then we can begin to change. Altering public stereotypes is not just a public relations problem of "educating the public." It requires us to change our own self-image, actions, and attitudes.

To succeed archivists must do two things. First, we must redefine our professional identity and our role in society. Then, we must develop a clear strategic vision for

${ }^{4}$ Sidney J. Levy and Albert G. Robles, The Image of Archivists: Resource Allocators' Perceptions (Chicago: Society of American Archivists, 1984); SAA Task Force on Archives and Society, "Archivists' Resource Allocators: The Next Step," unpublished report (9 December 1985), 4. 
improving services and responsiveness to archival customers. For many of us, this will require a reconceptualization of traditional methods, theories, and assumptions. In order to change old habits we need professional development in communication techniques, management, strategic planning, negotiation, motivation training, marketing, public relations, the nature and use of power, and other skills. ${ }^{5}$ It won't be easy. But it is necessary for survival. We can't afford not to change.

\section{What Business are Archivists in?}

What business are we in? What business are we not in? What business should we be in? In order to define our professional identity, we must pay serious attention to these questions. Easy traditional answers won't be enough. Consider what happened to the railroads. As marketing expert Theodore Levitt has argued, the railroads lost their national prominence largely because they assumed they were in the railroad business. They should have realized they were in the transportation business. Likewise, Hollywood thought it was in the movie business. The advent of television-a strong competitor in the entertainment business-nearly destroyed Hollywood. In both cases, industry leaders were product-oriented, instead of customer-oriented. ${ }^{6}$

According to Levitt, an organization "must learn to think of itself not as producing goods or services but as buying customers, as doing the things that will make people want to do business with it." $\mathrm{He}$ contends that an industry should develop backwards. Starting with a customer's needs, it should develop delivery systems to reach the consumer, then create things that will meet their needs, and finally find the nec-

\footnotetext{
5Ibid., 6 .

'Theodore Levitt, "Marketing Myopia," Harvard Business Review 38 (July/August 1960): 45-46; Naisbitt, Megatrends, 85-88.
}

essary raw materials. "The purpose of a business is to get and keep a customer," Levitt argues. "Customers are constantly presented with lots of options to help them solve their problems. They don't buy things, they buy solutions to problems." As the railroads discovered too late, people did not want to ride trains. They wanted to reach a particular destination. When they could do so more quickly by air, or more conveniently by car, they stopped riding trains.

Archivists can take a lesson here. We can't afford to continue making trains and preparing elaborate schedules, if people want quicker, more convenient transportation. Many have the illusion that a superior product will sell itself. It won't. It must meet a real customer need, not a hypothetical need derived from an existing product line. All too often archivists exhibit a product orientation, offering products and services which we think will be good for the public and are inherently desirable. When we take a more active stance, it often comes from a selling orientation, aimed at "persuading target audiences that they ought to accept the offering - that it is superior to any alternatives." Instead, we should adopt a marketing orientation: identify what information people need or want, then determine how to provide it, and finally discover where to find the raw materials. ${ }^{8}$ It isn't enough to try to sell the goods we already have on our shelves.

What business are archivists in? All too often, we assume it is the business of preserving records of the past for future use. Similar perceptions affect our "sister"

7Levitt, "Marketing Myopia," 55-56; Theodore Levitt, The Marketing Imagination (New York: Free Press, 1983), xii, 1-19; Philip Kotler, Marketing for Nonprofit Organizations, 2nd ed. (Englewood Cliffs, N. J.: Prentice-Hall, 1982), 19-26.

${ }^{8}$ Alan R. Andreasen, "Nonprofits: Check Your Attention to Customers," Harvard Business Review 60 (May/June 1982), 106; Levitt, "Marketing Myopia," 54; Kotler, Marketing for Nonprofit Organizations, 21-23. 
professions. As Philip Kotler and Sidney Levy reported in a 1969 article: "Most museum directors interpret their primary responsibility as 'the proper preservation of an artistic heritage for posterity.' As a result, for many people museums are cold marble mausoleums that house miles of relics that soon give way to yawns and tired feet." To counteract this, museums should pay closer attention to their users' concerns and needs. At the very least, public use and understanding of art should be part of their mission. As one marketing expert explains, art museums "compete with aquariums for family outings, and with movies and restaurants as places to socialize." Archivists face similar challenges.

\section{New Skills and Approaches}

Archives compete with other information services and cultural organizations, both for limited budgetary resources and for customers. In order to ensure their survival, archives must gain recognition as usefulbetter yet, essential-programs. How can we do this? There are no easy answers. If we wish to avoid the fate suggested by the Ghost of Archives Yet to Come, there are at least six actions we can take, individually and as a profession. To improve our competitive position, we will need to develop new skills and change our approach to basic archival activities.

Redefining Professional Identity and Role. We should begin by redefining our professional identity and role in society. As Sidney Levy states in The Image of Archivists, "To improve their situation, archivists need to define more coherent identity objectives, and communicate greater freshness and distinctiveness in imagery by their

${ }^{9}$ Philip Kotler and Sidnȩy J. Levy, "Broadening the Concept of Marketing," Jourmal of Marketing 33 (January 1969): 11; Andreasen, “Nonprofits," 109; Kevin Flood presentation at New England Archivists' Marketing Workshop, Amherst College, 22-23 March 1985. training, programs, self-assertion, publicity, advertising, and relevance to modern life." The problem, which archivists share with librarians and others, is not just how to project a more positive image, but how to reach agreement on exactly what image the profession wishes to send forth. Writing about librarians, Cosette Kies states the problem faced by archivists: "It should be no surprise, if we have no clear image of ourselves, that the public does not understand our purpose either."10

In Planning for the Archival Profession, the SAA Task Force on Goals and Priorities defines the profession's mission in the familiar triad of archival functions: " To insure the identification, preservation, and use of records of enduring value." This is how we usually define our business. Yet it bears a distinct product orientation. It emphasizes the records, not their informational content or the needs they satisfy. In discussing the goal of "availability and use of records," however, the GAP report acknowledges: "Archivists tend to think about their work in the order in which it is performed. Inevitably, use comes last. Since use of archival materials is the goal to which all other activities are directed, archivists need to re-examine their priorities."11 This begins to sound like a marketing orientation for archives.

Urging archivists to take a marketing approach, Kevin Flood, a member of SAA's Task Force on Archives and Society, suggests a starting point for defining what business we are in. We should stop thinking of ourselves as custodians, Flood argues, and think of ourselves as "information processors with outreach and administrative responsibility." These are action terms: information processors, not guardians; outreach, not collecting records and waiting

${ }^{10}$ Levy, Image of Archivists, v; Cosette Kies, Marketing and Public Relations for Libraries (Mctuchen, N. J.: Scarecrow Press, 1987), 45, 168.

11Planning for the Archival Profession, vi, 23. 
for the world to beat a path to our doors. Flood advises us "to enter into the information mainstream, to mold it to our needs, and to be part of the contemporary process instead of just a passive custodian of the past." One reason the archival profession does not ocupy a more prominent social role, Flood contends, is that it serves the ideology of the information custodian instead of the needs of people. ${ }^{12}$

Strategic Planning. As a second element in improving the competitive position of archives, strategic planning provides a process for defining our mission, goals, and objectives. In contrast to long-range planning, which is based on broad projections of internal growth and development, strategic planning "focuses on the external environment and the organization's ability to deal with it." Strategic planning clarifies the institution's purposes, provides a focus for program planning, and incorporates a systematic evaluation of alternatives. The process is based on the assumption that external conditions have a greater impact on the institution's ability to achieve its objectives than do the internal desires, goals, and intentions of managers and staff. Above all, it is action oriented. Grounded in a rigorous assessment of the organization's capabilities, strategic planning establishes goals and objectives, evaluates the potential impact of alternative choices, defines the necessary organizational changes to achieve desired results, and requires immediate actions. ${ }^{13}$

The GAP report has begun the process of planning the overall goals of the profession. Each repository should now under-

\footnotetext{
${ }^{12}$ Kevin Flood, "Address Prepared for Task Force on Society [sic] Presentation," unpublished paper (September 1984), 7; Flood, Marketing Workshop.

${ }^{13}$ Alice McHugh, "Strategic Planning for Museums," Museum News 58 (July/August 1980): 2327; Bruce W. Dearstyne, "Planning for Archival Programs: An Introduction," MARAC Technical Leaflet, Number 3, Mid-Atlantic Regional Archivist 12 (Summer 1983).
}

take its own strategic planning process. This includes clearly stating the repository's mission, goals, and objectives. By linking these directly to the institution's mission and goals, the archives obtains credibility and recognition as contributing to essential programs. In addition, by evaluating strategic alternatives, the archives assumes an active posture in seeking external support, resources, and recognition. The planning process also provides a solid basis for setting internal objectives and priorities.

Educating Resource Allocators. One additional benefit of strategic planning is that it compels archivists to respond to external forces and power structures, particularly in regard to resource allocators. This is the third action we must take for survival-convincing resource allocators that archives are essential. Archives must learn to compete effectively with other units and agencies for support and resources. "To raise this sense of priority, archivists should bring more to the fore the essential character of the archives," Sidney Levy suggests. "Allocators know archives are necessary by law and for research. But the purposes, uses, and contributions of the archives have to be made more vivid-more explicit, more concrete, and repeated in varied ways." 14 Administrators require us to serve present needs. It is not enough to preserve the past (old musty documents) for the future (when we'll all be dead). If archivists cannot meet today's needs for information, we will fall by the wayside.

Our multiple roles serving researchers, administrators, and other information handlers provide us with strategic advantages. Information is power. Our importance as archivists comes not from hoarding information, but from our ability to process data and assist others in using it. By showing resource allocators how they can use archival information to advantage, archivists

\footnotetext{
${ }^{14}$ Levy, Image of Archivists, iv.
} 
can enhance their claim on scarce resources.

In addition to the benefits derived from archival records, archivists have personal attributes that offer benefits to resource allocators. As stated in the SAA response to the Levy report, "Our training and interests stress the ability to analyze problems, develop hypotheses, draw conclusions, all of which makes us valuable as analysts in a variety of organizational settings." 15 We can apply our skills in information processing and analysis on a wider basis. This may include personal involvement on institutional committees and task forces. At the very least, archivists should be involved in planning and policy-making for records management and data systems. Current record-keeping concerns should be integrated with efforts to ensure preservation of essential information.

Becoming User-Friendly. Closely related to improving services and usefulness to resource allocators is a fourth, and perhaps most important, key to survival: becoming "user friendly." Archivists should adopt a marketing orientation to attract users and satisfy their needs for information. As Lawrence Dowler states, "If use is the measure and justification of archives, then reference should be first, not last, in operational priorities." All too often, we begin with the organization's needs and products, and then determine how to convince people to use archives. Instead, as Elsie Freeman argues, we need to reconceptualize our basic services and procedures from the user's point of view. Advanced technologies and information systems may make archives a backwater, Freeman warns, "not because our material is irrelevant to current or retrospective questions but rather because of the difficulty users have in reaching the information hidden in the records we hold."

\footnotetext{
15“Archivists' Resource Allocators," 4.
}

Convenience is critical for most information seekers. As Flood notes, users will follow the path of least resistance in seeking information. They expect speed, accuracy, and integrity of information. To meet these demands, archivists must develop new finding aids based on the convenience of users, not of archivists. ${ }^{16}$

Greater rigor and imagination in studying users and potential users will disclose their needs. As Freeman suggests, "We must begin to learn systematically, not impressionistically as is our present tendency, who our users are; what kinds of projects they pursue, in what time frames, and under what sponsorship; and, most importantly, how they approach records." Valuable models for designing user studies have been offered by Paul Conway and William J. Maher. In addition to improving services to users, user studies may have a secondary benefit. "The more archivists know about the use of their holdings," Maher suggests, "the more ammunition they will have in the battle to convince people that archives really matter." 17

In examining users of archives, the tendency has been to focus on archivists' needs. An instructive example of this is the effort by the Illinois State Archives to promote scholarly use of its holdings. The attempt failed, not because the records could not support scholarly use, but because the Archives had not evaluated the needs of its users. It reminds one of Theodore Levitt's

\footnotetext{
${ }^{16}$ Lawrence Dowler, "The Role of Use in Defining Archival Practice and Principles: A Research Agenda for the Availability and Use of Records," American Archivist 51 (Winter/Spring 1988): 84; Elsie T. Freeman, "In the Eye of the Beholder: Archives Administration From the User's Point of View," American Archivist 47 (Spring 1984): 112, 116; Flood, Marketing Workshop.

${ }^{17}$ Freeman, "In the Eye of the Beholder," 112; William J. Maher, "The Use of User Studies," Midwestern Archivist 11 (1986): 15; Paul Conway, "Facts and Frameworks: An Approach to Studying the Users of Archives,"' American Archivist 49 (Fall 1986): 393407.
} 
critique of Detroit's customer studies, which "only researched his preferences between the kinds of things which it had already decided to offer him." 18 A marketing orientation will ensure that archivists provide services based on the needs and desires of both users and potential users. A careful application of user studies can help us to identify these concerns.

We may need to begin by redefining our user constituencies. At the outset we need to recognize the various groups that make up our users. Archivists tend to develop finding aids and other services for scholarly researchers. Often, we have what Freeman characterizes as "adversary relationships" with genealogists and some other avocational users. The goal of archives, however, should be to encourage use of valuable records. All potential users of the archives should be assisted and appreciated. At the same time, archivists need to prioritize their decisions in order to focus on the groups that most need their materials and attention. ${ }^{19}$

Users can be a valuable constituency to assist archivists. For example, genealogists can be strong allies in seeking support for maintaining or expanding archival programs. Students and alumni of academic institutions, who often only want to see old yearbooks, campus papers, or course catalogs, can help justify the continuation of the archives. We should not under-rate the value of nostalgia. It is a powerful motivation for many users of archival information. An important area for investigation would be the underlying human needs which archival research can satisfy. We know a lot about the basic properties of our products-records, exhibitions, public programs-but very little about the

\footnotetext{
${ }^{18}$ Roy C. Turnbaugh, "Archival Mission and User Studies," Midwestern Archivist 11 (1986): 27-33; Levitt, "Marketing Myopia," 51.

${ }^{19}$ Freeman, "In the Eye of the Beholder," 113; Flood, "Address for Task Force on Society," 12.
}

psychological and informational needs that motivate users. For example, some people have a need to know information from the archives. Others may have a "nice-toknow" attitude. Information may be either essential, valuable, or simply interesting for different users. ${ }^{20}$

Marketing Archives. The actual marketing of archives is a fifth step in guaranteeing survival. Marketing for archives includes four major steps: analyzing the community we wish to serve; identifying, segmenting, and selecting target groups; designing and promoting appropriate programs tailored to the needs of each target group; and managing the process through research, planning, and evaluation. According to marketing expert Philip Kotler, nonprofit organizations face different marketing considerations than businesses. Nonprofits have multiple audiences to serve. They have multiple objectives, and must determine the relative importance of each. They provide services rather than physical goods. Finally, nonprofits are expected to operate in the public interest, since they often receive public funding, subsidies, or tax exemptions. ${ }^{21}$ In order to market archival services, we must understand these factors and how to turn them to our advantage.

As an important aspect of marketing, archival outreach efforts should become a higher priority. Visibility is essential. As Sidney Levy concludes in his study of resource allocators, "Making archives a more common and accessible concept, and doing more to open them to use and visiting, should diminish the various elements of dustiness and mustiness, sheer acquisitiveness, territoriality, and dead accumulation. Open houses, showcases, special events, celebrations, announcements of findings and

\footnotetext{
${ }^{20}$ Levitt, "Marketing Myopia," 54; Kies, Marketing and Public Relations, 171.

${ }^{21} \mathrm{Kies}$, Marketing and Public Relations, 74; Kotler, Marketing for Nonprofit Organizations, 9, 215-31.
} 
distinctive uses of archives, etc., will convey a greater sense of vitality."22 The best way to alter the public image of archives (and archivists) is to change our own attitudes and ways of doing things. Outreach is essential, both to inform the public of archival resources and services and to demonstrate responsiveness to user needs.

Many archivists and resource allocators resist publicizing their archives. Some fear that over-use will damage fragile documents. Others think that "serious" researchers already know enough about archives. "I don't know if the public needs to be informed," one resource allocator stated. "Most people aren't interested and have no need for archives in their day-today lives." 23 This typifies the attitudes archivists must overcome if we are to gain resources and appreciation for the value of our profession. Through marketing and outreach, archivists need to identify how to satisfy people's daily needs for archival information and services.

Outward-Looking Attitude. Finally, an essential key to survival is adopting a more positive, outward-looking attitude. Shouting "Archives are primary!" from the library steps won't help much. We need to show that they are. This will require anticipating and responding to user needs. Archivists will have to preserve the information people want, in formats they can use easily, with the quick access they demand.

Archivists are used to being humble. Compared to other virtues, however, modesty is highly over-rated. In order to improve our status, we need to become unabashed promoters of archives. "Archivists need to translate their importance into more power," Levy advises. "That requires more self-assertion, more concerted action, being less sympathetic to or understanding of the resource allocators' budget

\footnotetext{
${ }^{22}$ Levy, Image of Archivists, $\mathrm{v}$. ${ }^{23}$ Ibid., 60-61.
}

problems." 24 Constituencies served well can be counted on for support and lobbying. Researchers, genealogists, administrative support staff, and other archives users should be called on to tell resource allocators how valuable archival services are to them.

Archivists can survive the transition to a high-tech information society if they redefine their professional identity and role in society, undertake strategic planning, respond to the needs of resource allocators and public users, adopt a marketing and outreach orientation, and take a more assertive, outward-looking stance. The archivist's aspiration, however, should not be merely to survive. As Theodore Levitt points out, "Anybody can survive in some way or other, even the skid-row bum. The trick is to survive gallantly, to feel the surging impulse of commercial mastery; not just to experience the sweet smell of success, but to have the visceral feel of entrepreneurial greatness." 25 This should be our goal. Archivists should strive to become integral parts of the information society.

My own encounter with the Ghost of Archives Yet to Come has changed my perception of the archivist's role in society. In my own vow to reform, to begin a new life as a user-oriented archivist, I can echo Ebeneezer Scrooge: "I will live in the Past, the Present, and the Future. The Spirits of all three shall strive within me. I will not shut out the lessons that they teach." If Scrooge could change his ways, perhaps I can-perhaps all of us can. May our transformation be as successful as his. If it is we may earn the recognition Scrooge received (changing one word from Dickens's final tribute): "It was always said of him, that he knew how to keep Archives well, if any man alive possessed the knowledge.",26

\footnotetext{
${ }^{24}$ Ibid., iv

${ }^{25}$ Levitt, "Marketing Myopia," 56.

${ }^{26}$ Charles Dickens, $A$ Christmas Carol (London: Chapman and Hall, 1843), 165-66.
} 